University of Nebraska - Lincoln

DigitalCommons@University of Nebraska - Lincoln

$10-2018$

\title{
Effect of Stocking Rate on Growing Juvenile Sunshine Bass, Morone chrysops $\times$ M. saxatilis, in an Outdoor Biofloc Production System
}

\author{
Bartholomew W. Green \\ bart.green@usda.gov \\ Steven D. Rawles \\ USDA, Agricultural Research Service \\ Carl D. Webster \\ USDA, Agricultural Research Service \\ Matthew E. McEntire \\ USDA, Agricultural Research Service
}

Follow this and additional works at: https://digitalcommons.unl.edu/usdaarsfacpub

Part of the Agriculture Commons, and the Aquaculture and Fisheries Commons

Green, Bartholomew W.; Rawles, Steven D.; Webster, Carl D.; and McEntire, Matthew E., "Effect of Stocking Rate on Growing Juvenile Sunshine Bass, Morone chrysops $\times$ M. saxatilis, in an Outdoor Biofloc Production System" (2018). Publications from USDA-ARS / UNL Faculty. 2421.

https://digitalcommons.unl.edu/usdaarsfacpub/2421

This Article is brought to you for free and open access by the U.S. Department of Agriculture: Agricultural Research Service, Lincoln, Nebraska at DigitalCommons@University of Nebraska - Lincoln. It has been accepted for inclusion in Publications from USDA-ARS / UNL Faculty by an authorized administrator of DigitalCommons@University of Nebraska - Lincoln. 


\title{
Effect of Stocking Rate on Growing Juvenile Sunshine Bass, Morone chrysops $\times$ M. saxatilis, in an Outdoor Biofloc Production System
}

\author{
Bartholomew W. Green ${ }^{1}$, Steven D. Rawles, Carl D. Webster, \\ And Matthew E. McEntiRe \\ United States Department of Agriculture (USDA), Agricultural Research Service (ARS)-Harry K. \\ Dupree Stuttgart National Aquaculture Research Center, P.O. Box 1050, Stuttgart, Arkansas \\ 721601050, USA
}

\begin{abstract}
The biofloc technology production system is a production-intensifying management strategy used primarily for culturing tilapia and penaeid shrimp, both of which can consume the biofloc. Other fish can be grown in biofloc systems because the biofloc serves to maintain water quality, metabolizing the ammonia excreted by intensively fed fish. A dose-response study was conducted in an outdoor biofloc system to begin quantifying the stocking rate production function for sunshine bass, Morone chrysops $\times$ Morone saxatilis, advanced fingerlings. Sunshine bass $(2.9 \pm 0.2 \mathrm{~g} /$ fish $)$ were stocked into tanks at 50-250 fish $/ \mathrm{m}^{2}$ in $50 \mathrm{fish} / \mathrm{m}^{2}$ increments. After $94 \mathrm{~d}$, gross yields ranged from 1.4 to $3.1 \mathrm{~kg} / \mathrm{m}^{3}$ and were independent of stocking rate. Harvested fish were separated into two size groups: smaller than $115 \mathrm{~mm}$ total length (TL, target fish) and larger than $115 \mathrm{~mm}$ TL (jumper fish). Target fish increased linearly from 62 to $93 \%$ and jumpers decreased linearly from 38 to $7 \%$ of the population, respectively, as stocking rate increased. The outdoor biofloc system offers potential for intensifying the production of advanced sunshine bass fingerlings, but feed consumption appeared to be impeded by high total suspended solids concentrations. Further research is needed to optimize stocking rates and solids management.
\end{abstract}

\section{KEYWORDS}

advanced fingerlings, biofloc technology production system, hybrid striped bass, sunshine bass

The biofloc technology (BFT) production system is a production-intensifying management strategy used primarily for culturing tilapia, Oreochromis sp., and white shrimp, Litopenaeus vannamei, both of which can consume the biofloc. Phytoplankton, bacteria, zooplankton, microbial grazers, and particulate organic matter constitute the biofloc in the outdoor BFT system. Consequently, dietary protein content can be reduced without sacrificing growth (Avnimelech 1999). However, other fish can be grown in BFT production systems because the biofloc serves as a water quality management tool, metabolizing the feed nitrogen (ammonia) excreted by the densely stocked and intensively fed fish. One of the first published reports of using an outdoor

\footnotetext{
${ }^{1}$ Correspondence to: bart.green@ars.usda.gov
}

BFT production system to grow fish other than tilapia or marine shrimp described the successful culture of channel catfish, Ictalurus punctatus (Green 2010). Subsequently, channel catfish were grown to stocker (Green et al. 2014) or foodfish size (Schrader et al. 2011) in the BFT production system.

Commercial sunshine bass farmers use either a three-phase (Morris et al. 1999) or two-phase (direct stock; D'Abramo and Frinsko 2008) production system to produce market-size fish. Survival is higher when advanced fingerlings are stocked for growout compared to smaller phase I fish (Smith et al. 1990). Advanced fingerlings are produced in ponds during phase II of the three-phase system or during an extended phase I of the two-phase system. Direct stocking in growout ponds of 5-g fingerling sunshine 
bass yielded higher survival and production than stocking 3-g fingerlings (D'Abramo et al. 2004). However, more intensified production would be required to produce the $3-$ to $5-\mathrm{g}$ fingerlings for direct stocking of growout ponds. Intensification of the hatchery phase (phase I) of sunshine bass production has received considerable attention from researchers (Denson and Smith 1997; Ludwig 2003; Lindell et al. 2004; Ludwig and Lochmann 2007, 2009), but there is little published information on the intensified production of advanced fingerlings. Other than culture of palmetto bass, Morone saxatilis $\$ \times$ Morone chrysops $\hat{0}$, in a variant of an outdoor BFT production system (Milstein et al. 2001), there are no published reports on using the BFT production system for hybrid striped bass culture. The objective of this study was to initiate the process of quantifying the stocking rate production function in an outdoor, mixotrophic BFT production system.

\section{Materials and Methods}

This dose-response study was conducted outdoors at the U.S. Department of Agriculture ARS Harry K. Dupree Stuttgart National Aquaculture Research Center (HKDSNARC), Stuttgart, AR, USA, in nine 2.4-m diameter $\left(4.7 \mathrm{~m}^{2}, \quad 3.6 \mathrm{~m}^{3}\right)$ high-density polyethylene lined, wire-mesh framed tanks. One $1.865-\mathrm{kW}$ blower provided air continuously through two concentric lengths of high-efficiency antimicrobial diffuser tubing (Pentair Aquatic Eco-Systems, Apopka, FL, USA) on the bottom of each tank. An airlift pump moved water from each tank to an adjacent 74-L (operating volume) settling chamber; continuous settling chamber operation (ca. $2 \mathrm{~L} / \mathrm{min}$ flow rate) began on August 21, 2015. Settling chambers were drained as needed. Water was added to tanks only to replace losses to evaporation and draining of settling chamber.

Water with an established biofloc was used to fill tanks. Two weeks before stocking fish, each tank was fertilized with a single dose $(500 \mathrm{~g})$ of dried molasses and beet pulp (Sweet45; Westway Feed Products, New Orleans, LA, USA) and treated with $681 \mathrm{~g} \mathrm{NaCl}$ to ensure that chloride concentration exceeded $100 \mathrm{mg} / \mathrm{L}$. No other source of organic carbon, besides fish diet, was added to tanks. Feed-grade sodium bicarbonate (Church \& Dwight, Co., Princeton, NJ, USA) was added to each tank as needed to maintain $\mathrm{pH}$ and total alkalinity.

Sunshine bass $(1.2 \pm 0.4 \mathrm{~g} /$ fish $)$ from a local fish farm (Keo Fish Farm, Keo, AR, USA) were quarantined, fed for $2 \mathrm{wk}$, and stocked into tanks at 50, 75, 100, 125, 150, 175, 200, 225, and 250 fish $/ \mathrm{m}^{2}$ on July 7, 2015. Mean $( \pm$ SD) initial weight was $2.9 \pm 0.2 \mathrm{~g} / \mathrm{fish}(\mathrm{CV}=6.9 \%)$. Stocking rates were assigned randomly to tanks. The experimental protocol was approved (Approval Number 2015-003) by the HKDSNARC Institutional Animal Care and Use Committee and conformed to ARS Policies and Procedures 130.4 and 635.1.

On August 21, 2015, most of the fish in the 225-fish $/ \mathrm{m}^{2}$ tank died overnight. The cause of the fish mortality was unknown but may have been related to algal toxins released during an algal die-off as indicated by the decrease in chlorophyll $a$ concentration from $1346 \mathrm{mg} / \mathrm{m}^{3}$ on August 19 to $343 \mathrm{mg} / \mathrm{m}^{3}$ on August 26; concentrations of dissolved oxygen (DO) and water quality variables were within the acceptable limits during this time. Data from this tank were excluded from analyses and reporting.

Fish were fed a commercially formulated $45 \%$ protein, $12 \%$ lipid, 1.5-mm floating extruded diet (Cargill Animal Nutrition, Minneapolis, $\mathrm{MN}$, USA) prior to stocking and Days 1-10 of the experiment. Beginning Day 10 through Day 18 , this diet was fed 1:1 with a $40 \%$ protein, $10 \%$ lipid, 3.2-mm floating extruded diet (Cargill Animal Nutrition), after which the latter diet was fed for the remainder of the experiment. Fish in each tank were fed twice daily at about 0800 and $1500 \mathrm{~h}$. Feeding rate during the first week was $8 \%$ of the biomass at stocking, after which fish were fed as much as they would consume in $10 \mathrm{~min}$.

Water samples were collected from each tank between 0700 and $0800 \mathrm{~h}$, beginning $6 \mathrm{~d}$ before stocking fish and continuing at weekly intervals through the end of the experiment, and analyzed. Total ammonia-nitrogen $\left(\mathrm{NH}_{4}-\mathrm{N}\right)$ was analyzed fluorometrically using the $o$-phthaldialdehyde 
method in a flow injection system (Genfa and Dasgupta 1989). Nitrite-nitrogen $\left(\mathrm{NO}_{2}-\mathrm{N}\right.$, diazotization), nitrate-nitrogen $\left(\mathrm{NO}_{3}-\mathrm{N}\right.$, cadmium reduction), and soluble reactive phosphorus $\left(\mathrm{PO}_{4}-\mathrm{P}\right.$, ascorbic acid method) were analyzed using flow injection analysis according to the manufacturer's instructions (FIAlab 2500; FIAlab Instruments, Bellevue, WA, USA). Total alkalinity and total suspended solids (TSS) were measured using the methods of Eaton et al. (2005). Chlorophyll $a$ was extracted in 2:1 chloroform : methanol from phytoplankton (for this study, "phytoplankton" includes planktonic algae and cyanobacteria as well as those associated with the biofloc) previously filtered from water samples by using a $0.45-\mu \mathrm{m}$ pore size glass fiber filter, and the chlorophyll $a$ concentration in the extract was determined by spectroscopy (Lloyd and Tucker 1988). Sample $\mathrm{pH}$ was measured electrometrically.

DO concentration and water temperature in each tank were monitored continuously by a galvanic oxygen sensor (Type III, Oxyguard, Birkerød, Denmark) and a thermistor (Model 109, Campbell Scientific, Logan, UT, USA) connected to a datalogger (Model CR206 or CR1000, Campbell Scientific).

Fish were not fed $6 \mathrm{~d}$ prior to harvest and were harvested from tanks on October 8-9, 2015 (94 d after stocking). At harvest, the fish size distribution in each tank appeared bimodal and after some preliminary measurements fish were separated into two size groups: smaller than $115 \mathrm{~mm}$ total length (TL) and larger than $115 \mathrm{~mm}$ TL, denominated "target fish" and “jumpers," respectively. Individual weight (nearest $0.1 \mathrm{~g}$ ) and TL (nearest $\mathrm{mm}$ ) were measured and recorded for 100 small and 100 large fish (or all large fish for $n<100$ ) from each tank. All remaining fish in each size group were counted and weighed in bulk. Feed efficiency was calculated as the net weight of fish harvested divided by the total quantity of feed fed on a dry matter basis. Fulton's coefficient of condition $(K)$ was calculated as $K=100 \times$ weight/(length) ${ }^{3}$. Arbitrary samples of 10 fish each were collected for the determination of body compositional indices and whole-body composition, respectively.

Body compositional indices measured were:
Hepatosomatic index $(\mathrm{HSI})=$ liver mass $\times 100$ $\div$ (fish mass);

Viscerosomatic index $(\mathrm{VSI})=$ visceral mass $\times$ $100 \div$ (fish mass)

Visceral mass excluded the gonads, but included the entire abdominal wall fat.

Fish for whole-body analysis were frozen for later determination of proximate composition according to standard methods (AOAC 2005; AOCS 2009). Briefly, frozen whole bodies of initial fish taken at the beginning of the trials and fish from each pond or tank at the end of the trials were thawed, homogenized, and analyzed in aggregate as follows. Fish were individually ground into a fine paste using a Retsch knife mill (Grindomix GM300, Retsch GmbH, Haan, Germany) and the resulting homogenates were then pooled per treatment replicate (tank or initial fish) and thoroughly mixed for $1-2 \mathrm{~min}$ in a chilled stainless steel bowl using a commercial bench top mixer (Model A-200, Hobart, Inc., Troy, OH, USA). One aliquot of each homogenate was taken for moisture determination and another 100-g aliquot was packed into a plastic tray and lyophilized (FreeZone ${ }^{\circledR}$ Triad freeze-drier, Model 7400030, Labconco, Inc., Kansas City, MO, USA) prior to protein, lipid, and energy determinations. Lyophilized samples were ground in a container and blade assembly appropriate for the sample volume with a commercial blender (Blender 7011H, Model 31BL41, Waring Products Division, Dynamics Corporation of America, New Hartford, CT, USA) to produce a uniform powder for analysis.

Three subsamples of each freeze-dried, ground homogenate were analyzed and averaged to obtain one representative analyte value per treatment replicate (tank or initial fish). Moisture was determined after drying in a convection oven (Isotemp 750F, Fisher Scientific, Hanover Park, IL, USA). Protein $(\mathrm{N} \times 6.25)$ was determined by the Dumas method using a LECO nitrogen analyzer (FP428, LECO Corporation, St. Joseph, MI, USA). Total energy was determined by isoperibol bomb calorimetry (Parr1281, Parr Instrument Company, Inc., Moline, IL, USA). 
Lipid was quantified gravimetrically following petroleum ether extraction (AOCS 2009; Method AM 5-04) in an ANKOM ST15 lipid extractor (ANKOM Technology, Inc., Macedon, NY, USA). Protein or energy retention efficiency (RE) were determined by comparative slaughter and calculated as $\mathrm{RE}=$ protein or energy gain $\times 100$ /protein or energy fed.

Data were analyzed using the univariate, regression (REG), and frequency (FREQ) procedures of SAS version 9.4 (SAS Institute, Inc., Cary, NC, USA). Individual TL data were assigned to $10-\mathrm{mm}$ bins (target fish) or $20-\mathrm{mm}$ bins (jumper fish) for frequency analysis. Each bin contained fish greater than the lower bound and less than or equal to the upper bound; TL shown on the $x$-axis is the upper bound of each bin.

\section{Results}

Hybrid striped bass fingerlings survived and grew in the outdoor BFT system (Table 1). Gross and net fish yields ranged from 1.4 to $3.1 \mathrm{~kg} / \mathrm{m}^{3}$ and 1.2 to $2.7 \mathrm{~kg} / \mathrm{m}^{3}$, respectively, and were independent of stocking rate. Gross fish yield was independent of mean TSS concentration $\left(P=0.400, R^{2}=0.120\right)$. A partial fish die-off of unknown cause occurred in the $150-\mathrm{fish} / \mathrm{m}^{2}$ tank overnight on September 23; the fish exhibited no gross clinical signs, and DO and water quality variables were within the acceptable limits. Survival was independent of stocking rate and averaged $81.7 \%$ overall, excluding that of the $150-\mathrm{fish} / \mathrm{m}^{2}$ tank. Survival was independent of TSS concentration $\left(P=0.212, R^{2}=0.246\right)$ but decreased linearly $\left(P=0.012, R^{2}=0.750\right)$ when the $150-\mathrm{fish} / \mathrm{m}^{2}$ tank was excluded. Daily feed rates and total feed additions increased linearly with stocking rate. Feed efficiency and protein, energy, and lipid REs were independent of stocking rate.

Mean final weights of target fish ranged from 9.8 to $16.5 \mathrm{~g} /$ fish and decreased linearly with stocking rate (Table 2). Jumpers ranged in average weight from 40.3 to $55.5 \mathrm{~g} / \mathrm{fish}$, which were independent of stocking rate. Final weight $\mathrm{CV}$ for target fish increased linearly with stocking rate $\left(P=0.003, R^{2}=0.786\right)$ but was independent $\left(P=0.149, R^{2}=0.314\right)$ of stocking rate for jumpers. Final weight $\mathrm{CV}$ ranged from 28 to $46 \%$ and 29 to $60 \%$ for target and jumpers, respectively. Mean final TL ( $y$, $\mathrm{mm} /$ fish) decreased significantly as stocking rate $(x)$ increased and is described by the equations: $y=109.470-0.0837 x \quad\left(P<0.001, R^{2}=0.919\right)$ and $\quad y=149.989-0.0653 x \quad(P=0.011$, $R^{2}=0.687$ ) for target fish and jumpers, respectively. Final length $\mathrm{CV}$ increased linearly with stocking rate $\left(P=0.010, R^{2}=0.698\right)$ for target fish and trended negative $(P=0.077$, $\left.R^{2}=0.432\right)$ for jumpers. Fulton's $K$ was independent $\left(P=0.794, R^{2}=0.012\right.$ and $P=0.637$, $R^{2}=0.040$, respectively) of stocking rate, averaging 1.4 and 1.7 for target and jumper fish, respectively. Body compositional indices were independent of stocking rate (Table 2).

Two distinct sunshine bass size groups were observed in all tanks at harvest (Fig. 1). Results of chi-square analysis showed that size distributions of target and jumper fish shifted significantly $(P<0.001)$ toward smaller sizes with increasing stocking rate. In response to increased stocking rate, target fish increased linearly from 62 to $93 \%$ and jumpers decreased linearly from 38 to $7 \%$ of the population, respectively (Fig. 2).

Mean water quality data are shown in Table 3. Mean $\mathrm{NH}_{4}-\mathrm{N}$ and $\mathrm{NO}_{2}-\mathrm{N}$ concentrations were low and independent of stocking rate. The linear increase in mean $\mathrm{NO}_{3}-\mathrm{N}, \mathrm{PO}_{4}-\mathrm{P}$, and TSS in response to increased stocking rate likely reflected the linear increase $(P<0.013)$ of these variables in response to total feed input ( $R^{2}=0.821,0.674$, and 0.723 , respectively). Mean chlorophyll a concentration was high in all tanks but independent of stocking rate. Chlorophyll $a$ concentration in individual tanks varied from 200 to $1800 \mathrm{mg} / \mathrm{m}^{3}$ throughout the study and did not appear to be affected by settling chamber operation. TSS concentration in individual tanks ranged from 400 to $1000 \mathrm{mg} / \mathrm{L}$ and from 200 to $600 \mathrm{mg} / \mathrm{L}$ before and after settling chamber activation. Mean early morning and daily DO each exceeded $85.9 \%$ saturation $(6.6 \mathrm{mg} / \mathrm{L})$. Mean monthly water temperature decreased from $31.3 \mathrm{C}$ in July to $20.1 \mathrm{C}$ in October; overall mean water temperature was 27.4 C. 
TABLE 1. GFY $\left(\mathrm{kg} / \mathrm{m}^{3}\right), \operatorname{NFY}\left(\mathrm{kg} / \mathrm{m}^{3}\right)$, survival (\%), mean daily feed $\left(\mathrm{g} / \mathrm{m}^{3} / \mathrm{d}\right)$, total feed $\left(\mathrm{kg} / \mathrm{m}^{3}\right)$, feed efficiency, PRE (\%), ERE (\%), and lipid RE (\%) for sunshine bass fingerlings grown for 94 d at different stocking rates $\left(\right.$ fish $\left./ \mathrm{m}^{2}\right)$ in outdoor biofloc technology production system tanks.

\begin{tabular}{lccccccccc}
\hline & & & & \multicolumn{3}{c}{ Feed } & & \\
\cline { 7 - 8 } Stocking rate & GFY & NFY & Survival & Daily & Total & Efficiency & PRE & ERE & Lipid RE \\
\hline 50 & 1.4 & 1.2 & 85.4 & 38.4 & 4.9 & 0.30 & 9.7 & 10.7 & 41.3 \\
75 & 2.5 & 2.2 & 86.3 & 52.0 & 6.7 & 0.39 & 13.0 & 13.7 & 52.5 \\
100 & 3.1 & 2.7 & 86.7 & 58.2 & 7.6 & 0.42 & 14.2 & 15.3 & 59.6 \\
125 & 2.7 & 2.2 & 82.0 & 58.6 & 7.5 & 0.38 & 11.4 & 12.9 & 49.5 \\
150 & 2.1 & 1.6 & 39.4 & 74.3 & 9.5 & 0.24 & 6.6 & 7.5 & 31.2 \\
175 & 2.4 & 1.8 & 74.9 & 67.2 & 8.7 & 0.29 & 7.9 & 8.5 & 32.3 \\
200 & 3.1 & 2.4 & 74.0 & 71.4 & 9.1 & 0.36 & 10.1 & 11.4 & 43.5 \\
250 & 3.1 & 2.2 & 82.7 & 72.3 & 9.3 & 0.35 & 9.5 & 10.5 & 43.7 \\
Regression & NS & NS & NS & Linear & Linear & NS & NS & NS & NS \\
$P>F$ & 0.112 & 0.464 & 0.131 & 0.005 & 0.006 & 0.739 & 0.275 & 0.301 & 0.382 \\
$R^{2}$ & 0.425 & 0.112 & 0.394 & 0.757 & 0.745 & 0.020 & 0.194 & 0.176 & 0.129 \\
\hline
\end{tabular}

$\mathrm{ERE}=$ energy RE; GFY = gross fish yield; $\mathrm{NFY}=$ net fish yield; $\mathrm{NS}=$ not significant; $\mathrm{PRE}=$ protein $\mathrm{RE} ; \mathrm{RE}=$ retention efficiency.

\section{Discussion}

Sunshine bass have been grown successfully at high stocking and feeding rates in vertical raceways (Volkman et al. 2004) and recirculating aquaculture systems (RAS; Kemeh and Brown 2001; Rawles et al. 2006), but this is the first report of growing sunshine bass in a near-zero-water-exchange BFT production system. Phytoplankton uptake and nitrification in the outdoor BFT system function to maintain good water quality, mainly low $\mathrm{NH}_{4}-\mathrm{N}$ and $\mathrm{NO}_{2}-\mathrm{N}$ concentrations, in response to high feeding rates, which combined with high stocking and aeration rates, increase fish yields.

Fish yield generally increases with stocking rate when feed is not limiting until the stocking biomass equals the carrying capacity (Hepher 1978). The absence of a positive stocking rate-fish yield relationship in the present experiment was contrary to the results reported by others for larval (Ludwig and Lochmann 2007), stocker (Kemeh and Brown 2001; Potthoff and Christman 2006), and food size (D'Abramo et al. 2004) sunshine bass for a variety of culture environments. In a 121-d study in prototype floating vertical raceways stocked with juvenile sunshine bass at 125 or $188 \mathrm{fish} / \mathrm{m}^{3}$, mean gross fish yields did not differ significantly and were 18.9 and $16.2 \mathrm{~kg} / \mathrm{m}^{3}$, respectively, but mean final weight was significantly lower at the higher stocking rate. Gross fish yield increased linearly with stocking rate when juvenile sunshine bass stocked for two experiments in RAS tanks at $100-300 / \mathrm{m}^{3}$ and $150-725 / \mathrm{m}^{3}$, but weight gain was independent of stocking rate (Kemeh and Brown 2001). Similarly, gross fish yield of juvenile largemouth bass (LMB), Micropterus salmoides, stocked at $1667-4444 \mathrm{fish} / \mathrm{m}^{3}$ (Park et al. 2015) or stocker size LMB stocked at 30-120 fish $/ \mathrm{m}^{3}$ (Watts et al. 2016) in RAS increased linearly with stocking rate, but fish growth, based on average weight at harvest, appeared independent of stocking rate.

In contrast to the results mentioned above where growth appeared independent of stocking rate, social interactions among fish as a result of stocking density have been shown to influence individual fish growth (Jobling and Wandsvik 1983; Huss et al. 2008). The most common social interaction among individuals of a fish population is competition for food, which results in growth depensation (Brett 1979). If food is assumed to be distributed according to a size hierarchy, then size variation (as measured by the $\mathrm{CV}$ ) would be exacerbated as competition intensifies. Stocking rate is one factor that could increase competition and variation in final fish size. The bimodal size distribution and increase in target fish size variation with stocking rate observed in the present experiment suggested 
TABLE 2. Mean individual weigh at harvest ( $\mathrm{g} /$ fish), HSI (\%) and VSI (\%), and whole-body compositional analyses (\%; fresh weight basis) for target size $(\leq 115 \mathrm{~mm} T L)$ and jumper size $(>115 \mathrm{~mm} T L)$ sunshine bass fingerlings grown for $94 \mathrm{~d}$ at different stocking rates ( $\mathrm{fish} / \mathrm{m}^{2}$ ) in outdoor biofloc technology production system tanks.

\begin{tabular}{|c|c|c|c|c|c|c|c|}
\hline \multirow[b]{2}{*}{ Stocking rate } & \multirow[b]{2}{*}{ Final weight } & \multirow[b]{2}{*}{ HSI } & \multirow[b]{2}{*}{ VSI } & \multicolumn{4}{|c|}{ Whole-body composition } \\
\hline & & & & Protein & Lipid & Energy & Moisture \\
\hline \multicolumn{8}{|l|}{ Target size } \\
\hline 50 & 14.8 & 2.1 & 8.5 & 15.3 & 9.9 & 1855.1 & 69.1 \\
\hline 75 & 16.3 & 2.6 & 8.9 & 15.6 & 9.5 & 1813.6 & 69.3 \\
\hline 100 & 16.5 & 3.0 & 10.6 & 15.6 & 10.0 & 1882.7 & 68.2 \\
\hline 125 & 13.4 & 2.4 & 9.8 & 15.7 & 9.9 & 1862.5 & 68.8 \\
\hline 150 & 12.8 & 4.1 & 9.8 & 15.4 & 10.8 & 1969.0 & 67.3 \\
\hline 175 & 11.7 & 3.0 & 9.3 & 15.6 & 9.34 & 1814.7 & 69.5 \\
\hline 200 & 12.9 & 3.3 & 9.8 & 15.4 & 10.2 & 1889.2 & 68.7 \\
\hline 250 & 9.8 & 2.6 & 10.0 & 15.6 & 10.6 & 1834.1 & 68.7 \\
\hline Regression & Linear & NS & NS & NS & NS & NS & NS \\
\hline$P>F$ & 0.005 & 0.550 & 0.241 & 0.728 & 0.268 & 0.929 & 0.768 \\
\hline$R^{2}$ & 0.765 & 0.063 & 0.220 & 0.022 & 0.199 & 0.001 & 0.016 \\
\hline \multicolumn{8}{|l|}{ Jumper size } \\
\hline 50 & 42.3 & 2.4 & 11.4 & 15.8 & 11.9 & 2041.2 & 66.9 \\
\hline 75 & 55.5 & 2.7 & 10.9 & 15.6 & 11.3 & 1936.4 & 67.8 \\
\hline 100 & 54.4 & 3.1 & 10.4 & 16.0 & 12.0 & 2001.9 & 67.4 \\
\hline 125 & 44.9 & 2.3 & 11.6 & 15.0 & 11.7 & 2011.3 & 67.6 \\
\hline 150 & 48.3 & 3.4 & 10.7 & 15.9 & 11.5 & 1911.1 & 68.0 \\
\hline 175 & 50.5 & 2.9 & 9.2 & 15.5 & 10.4 & 1807.3 & 69.7 \\
\hline 200 & 40.9 & 4.0 & 12.0 & 14.8 & 10.3 & 1852.2 & 69.1 \\
\hline 250 & 35.5 & 2.3 & 11.8 & 14.5 & 10.9 & 1779.7 & 69.1 \\
\hline Regression & NS & NS & NS & Linear & Linear & Linear & Linear \\
\hline$P>\mathrm{F}$ & 0.129 & 0.377 & 0.699 & 0.033 & 0.044 & 0.004 & 0.007 \\
\hline$R^{2}$ & 0.341 & 0.131 & 0.023 & 0.560 & 0.520 & 0.771 & 0.725 \\
\hline
\end{tabular}

$\mathrm{HSI}=$ hepatosomatic index; NS = not significant; TL = total length; VSI = viscerosomatic index.

a feeding hierarchy whereby the larger fish limited feeding behavior of subordinates despite fish being fed (overfed) to apparent satiation. The feeding hierarchy likely resulted in the density-dependent growth observed for the target fish.

Stocking rate also impacted the population structure at harvest (Fig. 2). While the exact cause of this outcome is not known, competition for food or some breakdown of normal behavior remain as plausible explanations. The negative TL (growth)-stocking rate relationship observed for each size cohort supports the food competition explanation. Further research is needed to determine if additional increases in stocking rate reduce further the proportion of jumper fish. Such an outcome would impact positively sunshine bass production practices not only by increasing productivity, but also by reducing the need to grade fish prior to stocking for growth to food fish size.
Whole-body composition results were consistent with results reported for sunshine bass by others (Kelly and Kohler 1996; Rudacille and Kohler 2000; Burr et al. 2006; Turano et al. 2007). REs, however, were poor because of the poor feed efficiencies that resulted from overfeeding the fish. Feed efficiency reported for sunshine bass ranges from 0.37 to 0.94 (Kelly and Kohler 1996; D’Abramo et al. 2004; Volkman et al. 2004; Rawles et al. 2009). Although fish were fed daily to apparent satiation, several factors likely contributed to the overfeeding. All tanks had a well-developed biofloc and the water was brown in color despite high chlorophyll $a$ concentration. Diatoms, small chlorophytes, and a very small filamentous cyanobacteria are found closely associated with biofloc particles in the outdoor BFT system (Schrader et al. 2011; Green et al. 2014). Visibility in the water column was limited because of the high TSS concentrations. To the observer, there appeared to 

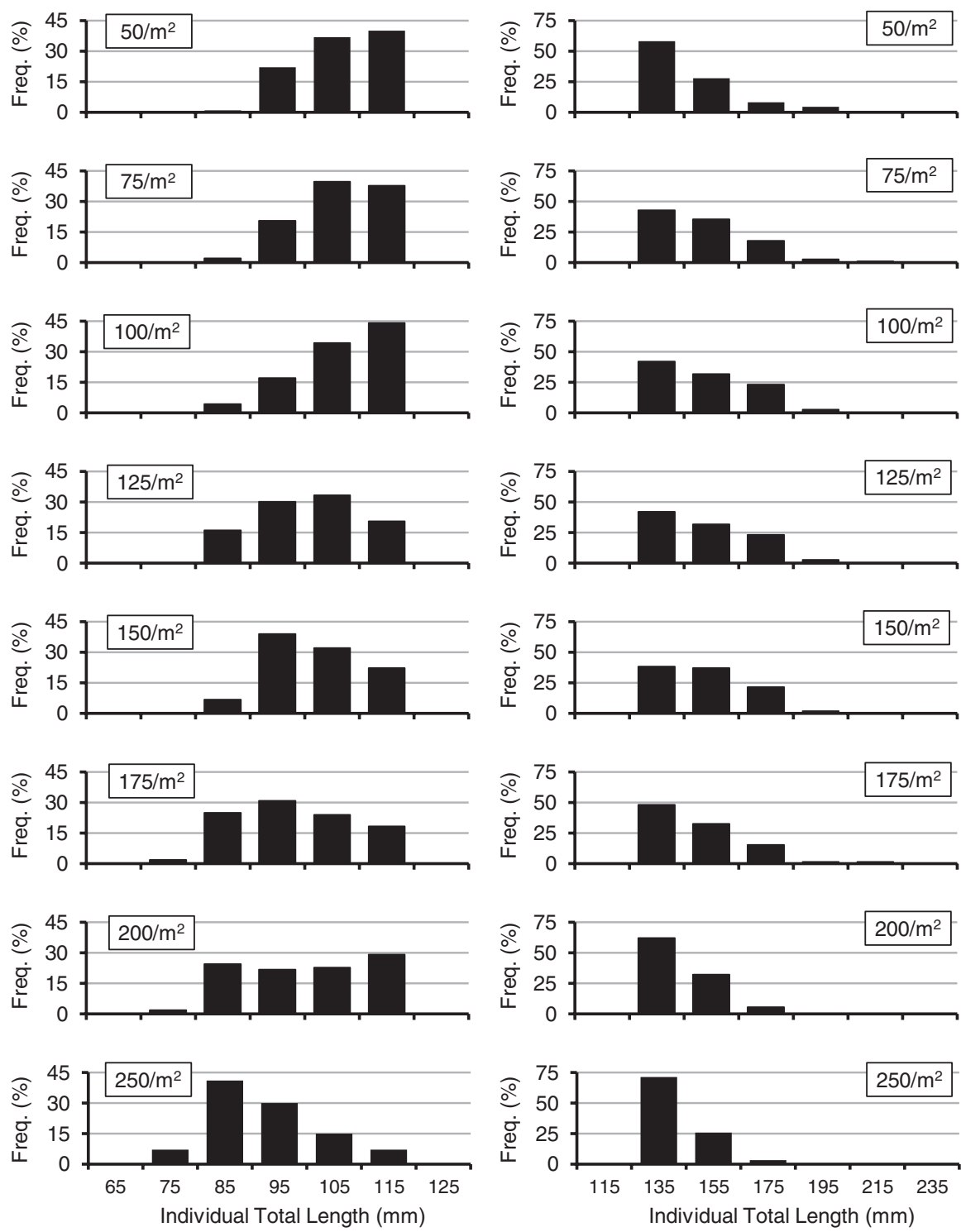

FIGURE 1. Length frequency distributions of target size ( $<115 \mathrm{~mm}$; left) and jumper size ( $>115 \mathrm{~mm}$; right) juvenile sunshine bass stocked at 50-250 fish $/ \mathrm{m}^{2}$ in the biofloc production system.

be only minor contrast between the water color and the color of the small feed pellets. These factors coupled with the constant aeration-induced water movement likely limited the ability of the fish to distinguish and consume the feed pellets. Likewise, it is likely that the person feeding the fish may have found it difficult at times to judge accurately the quantity of uneaten feed, resulting in the overfeeding.
Although overall fish survival was acceptable and within limits reported for growing sunshine bass fingerlings in ponds (D'Abramo et al. 2004; Turano et al. 2007) or in a prototype floating vertical raceway (Volkman et al. 2004), the mechanism by which TSS concentration appeared to affect sunshine bass survival negatively is not known. In larval sunshine bass production in tanks, increasing survival was associated with 


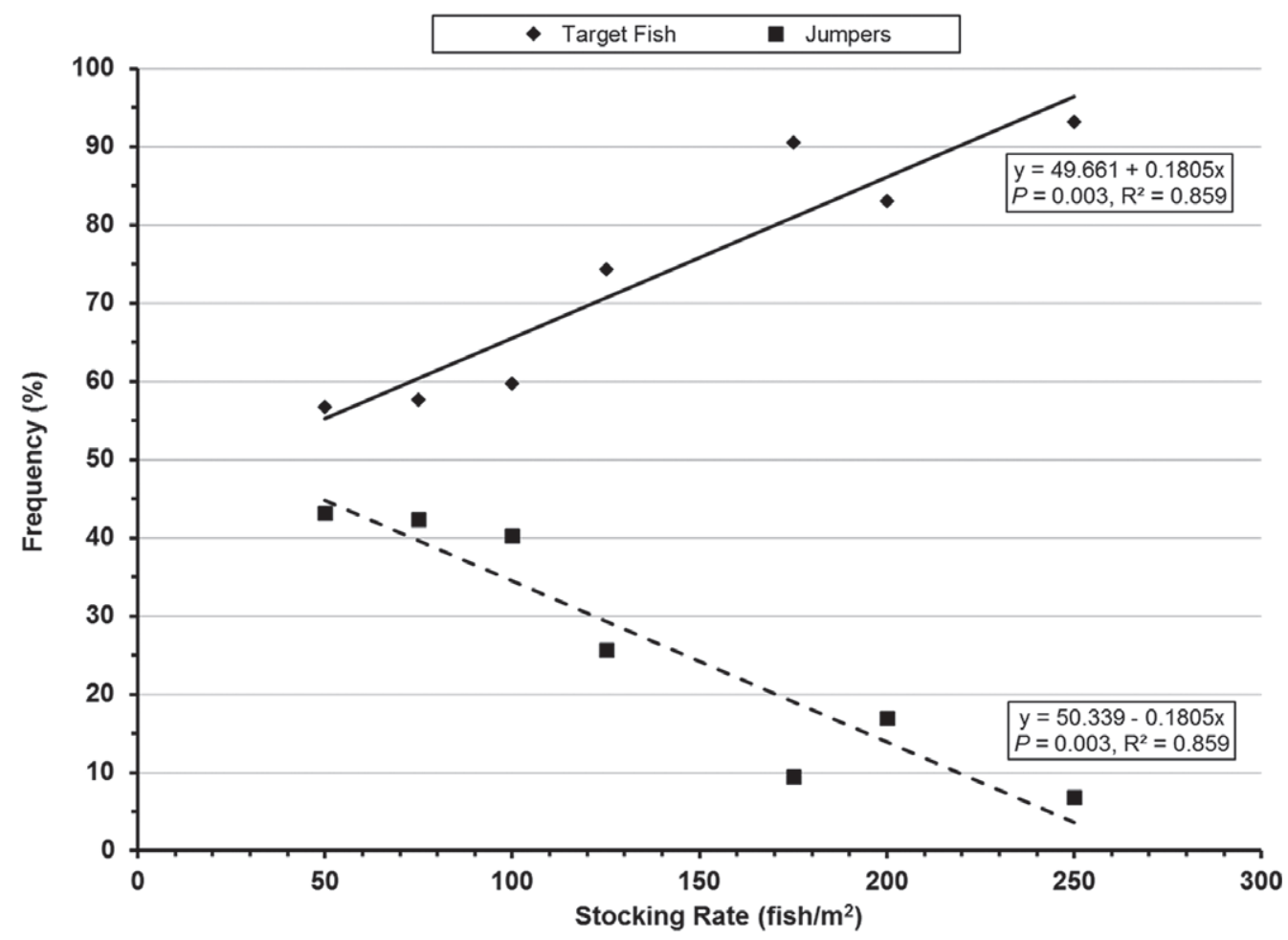

FIGURE 2. Proportion of the fish population at harvest composed of target size $(<115 \mathrm{~mm}$; solid line $)$ and jumper size (>115 mm; broken line) juvenile sunshine bass stocked at $50-250 \mathrm{fish} / \mathrm{m}^{2}$ in the biofloc production system.

TABLE 3. Mean concentrations $(\mathrm{mg} / \mathrm{L})$ of $\mathrm{NH}_{4}-\mathrm{N}, \mathrm{NO}_{2}-\mathrm{N}, \mathrm{NO}_{3}-\mathrm{N}$ and $\mathrm{PO}_{4}-\mathrm{P}$, TSS, and $\mathrm{Chl}$ a $\left(\mathrm{mg} / \mathrm{m}^{3}\right)$ in outdoor biofloc technology production system tanks used for growing sunshine bass fingerlings at different stocking rates $\left(\right.$ fish/m $\left.{ }^{2}\right)$ for $94 \mathrm{~d}$.

\begin{tabular}{|c|c|c|c|c|c|c|}
\hline Stocking rate & $\mathrm{NH}_{4}-\mathrm{N}$ & $\mathrm{NO}_{2}-\mathrm{N}$ & $\mathrm{NO}_{3}-\mathrm{N}$ & $\mathrm{PO}_{4}-\mathrm{P}$ & TSS & Chl $a$ \\
\hline 50 & 0.17 & 0.97 & 44.56 & 2.20 & 458.2 & 1016.0 \\
\hline 75 & 0.47 & 1.67 & 77.13 & 5.54 & 511.7 & 1094.3 \\
\hline 100 & 0.19 & 0.78 & 89.11 & 5.60 & 500.8 & 757.4 \\
\hline 125 & 0.86 & 2.44 & 81.20 & 4.79 & 481.8 & 669.8 \\
\hline 150 & 0.37 & 0.94 & 92.16 & 5.61 & 581.7 & 689.8 \\
\hline 175 & 0.19 & 0.96 & 91.80 & 5.30 & 622.9 & 1028.4 \\
\hline 200 & 0.46 & 1.34 & 117.06 & 7.75 & 622.0 & 806.5 \\
\hline 250 & 0.50 & 2.98 & 134.26 & 8.07 & 562.9 & 868.3 \\
\hline Regression & NS & NS & Linear & Linear & Linear & NS \\
\hline$P>F$ & 0.579 & 0.230 & $<0.001$ & 0.009 & 0.030 & 0.520 \\
\hline$R^{2}$ & 0.055 & 0.229 & 0.873 & 0.708 & 0.570 & 0.072 \\
\hline
\end{tabular}

Chl $a=$ chlorophyll $a ; \mathrm{NH}_{4}-\mathrm{N}=$ total ammonia-nitrogen; $\mathrm{NO}_{2}-\mathrm{N}=$ nitrite-nitrogen; $\mathrm{NO}_{3}-\mathrm{N}=$ nitrate-nitrogen; NS = not significant; $\mathrm{PO}_{4}-\mathrm{P}=$ soluble reactive phosphorus; TSS = total suspended solids.

elevated turbidity levels and was attributed to a decrease in cannibalistic interactions between the fish (McEntire et al. 2015). Of the few published reports on the effects of TSS on survival in BFT systems, most address white shrimp production and survival, which is (Schveitzer et al. 2013; Gaona et al. 2016) or is not (Ray et al.
2010, 2011) affected by TSS concentration. Survival of larval South American catfish, Rhamdia quelen, grown in a BFT system maintained at 157-909 mg/L TSS did not differ significantly (Poli et al. 2015). It was hypothesized that TSS-induced gill occlusion impeded respiration and osmoregulation and was responsible for 
increased shrimp mortality as TSS concentration increased (Schveitzer et al. 2013).

Indeed, reducing solids may impact positively survival and growth of juvenile sunshine bass. Reducing TSS concentration in our outdoor BFT system did not affect chlorophyll $a$ concentrations compared to no solids removal and resulted in brownish-green water (B. Green, USDA-ARS, unpublished data), which should increase contrast between the feed pellet and tank water. Improved feed efficiency would be expected because both the fish and feeder would be able to see the feed pellet. Further research is needed to clarify the relationship between TSS concentration and growth and survival of juvenile sunshine bass in the outdoor BFT system.

On the whole, results of the current study indicated that the outdoor BFT production system offers potential for intensifying the production of advanced sunshine bass fingerlings. Growing larval fish indoors through the live-feed stage, followed by transfer to an outdoor BFT production system as they transition to formulated diets could improve production efficiency of advanced fingerlings. However, further research is needed to optimize stocking rates and solids management, after which an economic analysis must be performed.

\section{Acknowledgments}

We thank Greg O'Neal, Rebecca Roberts, Paxton Harper, Jonathan Schiederer, and Chris Schiederer for their assistance. Mention of trade names or commercial products is solely for the purpose of providing specific information and does not imply recommendation or endorsement by the US Department of Agriculture (USDA). USDA is an equal opportunity provider and employer.

\section{Literature Cited}

AOAC (Association of Official Analytical Chemists). 2005. Official methods of analysis of AOAC International, 18th edition. AOAC International, Gaithersburg, Maryland, USA.

AOCS (American Oil Chemists Society). 2009. Official methods and recommended practices of the American Oil Chemists Society, 6th edition. American Oil Chemists Society, Urbana, Illinois, USA.
Avnimelech, Y. 1999. Carbon/nitrogen ratio as a control element in aquaculture systems. Aquaculture 176:227-235.

Brett, J. R. 1979. Environmental factors and growth. Pages 599-675 in W. S. Hoar, D. J. Randall, and J. R. Brett, editors. Fish physiology, Volume VIII. Academic Press, New York, New York, USA.

Burr, G. S., P. Li, J. B. Goff, D. M. Gatlin III., B. Grisdale-Helland, and S. J. Helland. 2006. Evaluation of growth performance and whole-body composition of juvenile hybrid striped bass Morone chrysops x M. saxatilis and red drum Sciaenops ocellatus fed high-protein and high lipid diets. Journal of the World Aquaculture Society 37:421-430.

D'Abramo, L. R. and M. O. Frinsko. 2008. Hybrid striped bass: pond production of food fish. Southern Regional Aquaculture Center (SRAC) Publication 303. Southern Regional Aquaculture Center, Mississippi State University, Stoneville, Mississippi, USA.

D'Abramo, L. R., C. L. Ohs, and T. R. Hanson. 2004. Effect of stocking weight and stocking density on production of hybrid striped bass (sunshine) in earthen ponds in the second phase of a 2-phase system. Journal of the World Aquaculture Society 35:33-45.

Denson, M. R. and T. I. Smith. 1997. Communications: tank culture of larval sunshine bass. The Progressive Fish-Culturist 59:59-63.

Eaton, A. D., L. S. Clesceri, E. W. Rice, and A. E. Greenberg. 2005. Standard Methods for the Examination of Water and Wastewater, $21^{\text {st }}$ Edition. American Public Health Association, Washington, Districut of Columbia, USA.

Gaona, C. A. P., F. da Paz Serra, P. S. Furtado, L. H. Poersch, and W. Wasielesky. 2016. Effect of different total suspended solids concentrations on the growth performance of Litopenaeus vannamei in a BFT system. Aquacultural Engineering 72:65-69.

Genfa, Z. and P. K. Dasgupta. 1989. Fluorometric measurement of aqueous ammonium ion in a flow injection system. Analytical Chemistry 61:408-412.

Green, B. W. 2010. Effect of channel catfish stocking rate on yield and water quality in an intensive, mixed suspended-growth production system. North American Journal of Aquaculture 72:97-106.

Green, B. W., K. K. Schrader, and P. W. Perschbacher. 2014. Effect of stocking biomass on solids, phytoplankton communities, common off-flavors, and production parameters in a channel catfish biofloc technology production system. Aquaculture Research 45:1442-1458.

Hepher, B. 1978. Ecological aspects of warm-water fishpond management. Pages 447-468 in S. D. Gerking, editor. Ecology of freshwater fish production. Halstead Press, New York, New York, USA.

Huss, M., P. Bystrom, and L. Persson. 2008. Resource heterogeneity, diet shifts and intra-cohort competition: effects on size divergence in YOY fish. Oecologia 158:249-257.

Jobling, M. and A. Wandsvik. 1983. Effect of social interactions on growth rates and conversion efficiency 
of Arctic charr, Salvelinus alpinus L. Journal of Fish Biology 22:577-584.

Kelly, A. M. and C. C. Kohler. 1996. Sunshine bass performance in ponds, cages, and indoor tanks. The Progressive Fish-Culturist 58:55-58.

Kemeh, S. and P. B. Brown. 2001. Evaluation of different stocking densities for hybrid striped bass in small-scale recirculation systems. North American Journal of Aquaculture 63:234-237.

Lindell, S. R., B. Delbos, R. Perham, J. Goldman, E. M. Hallerman, and T. O. Brenden. 2004. Hatchery and grow-out performance of sunshine bass and backcross hybrid striped bass in recirculating aquaculture systems. International Journal of Recirculating Aquaculture 5:1.

Lloyd, S. W. and C. S. Tucker. 1988. Comparison of three solvent systems for extraction of chlorophyll $a$ from fish pond phytoplankton communities. Journal of the World Aquaculture Society 19:36-40.

Ludwig, G. M. 2003. Tank culture of larval sunshine bass, Morone chrysops (Rafinesque) $\times M$. saxatilis (Walbaum), at three feeding levels. Aquaculture Research 34:1277-1285.

Ludwig, G. M. and S. E. Lochmann. 2007. Effect of tank stocking density on larval sunshine bass growth and survival to the fingerling stage. North American Journal of Aquaculture 69:407-412.

Ludwig, G. M. and S. E. Lochmann. 2009. Tank culture of sunshine bass fingerlings without using rotifers. North American Journal of Aquaculture 71:224-228.

McEntire, M., M. Riche, B. H. Beck, and D. Carter. 2015. Effect of contrasting agents on survival, performance, and condition of larval hybrid striped bass Morone chrysops x M. saxatilis in tanks. Journal of Applied Aquaculture 27:1-28.

Milstein, A., Y. Avinemelch, M. Zoran, and D. Joseph. 2001. Growth performance of hybrid bass and hybrid tilapia in conventional and active suspension intensive ponds. Israeli Journal of Aquaculture - Bamidgeh 53:147-157.

Morris, J. E., C. C. Kohler, and C. C. Mischke. 1999. Pond culture of hybrid striped bass in the North Central Region. North Central Regional Aquaculture Center (NCRAC) Publication 107. North Central Regional Aquaculture Center, Iowa State University, Ames, Iowa, USA.

Park, J., N. Renukdas, T. Luna, and L. A. Roy. 2015. The effects of biomass density on size variability and growth performance of juvenile largemouth bass, Micropterus salmoides, in a semi-closed recirculating system. Journal of the World Aquaculture Society 46:283-291.

Poli, M. A., R. Schveitzer, and A. Pires de Oliveira Nuñer. 2015. The use of biofloc technology in a South American catfish (Rhamdia quelen) hatchery: effect of suspended solids in the performance of larvae. Aquacultural Engineering 66:17-21.

Potthoff, M. T. and M. C. Christman. 2006. Growth depensation and group behaviour in juvenile hybrid striped bass Morone chrysops $\times$ Morone saxatilis: effects of group membership, feeding method, ration size and size disparity. Journal of Fish Biology 69:828-845.

Rawles, S. D., M. Riche, T. G. Gaylord, J. Webb, D. W. Freeman, and M. Davis. 2006. Evaluation of poultry by-product meal in commercial diets for hybrid striped bass (Morone chrysops $\$ \times M$. saxatilis $\widehat{0}$ ) in recirculated tank production. Aquaculture 259:377-389.

Rawles, S. D., T. G. Gaylord, M. E. McEntire, and D. W. Freeman. 2009. Evaluation of poultry by-product meal in commercial diets for hybrid striped bass, Morone chrysops $+\times M$. saxatilis ${ }^{\star}$, in pond production. Journal of the World Aquaculture Society 40:141-156.

Ray, A. J., B. L. Lewis, C. L. Browdy, and J. W. Leffler. 2010. Suspended solids removal to improve shrimp (Litopenaeus vannamei) production and an evaluation of a plant-based feed in minimal-exchange, superintensive culture systems. Aquaculture 299:89-98.

Ray, A. J., K. S. Dillon, and J. M. Lotz. 2011. Water quality dynamics and shrimp (Litopenaeus vannamei) production in intensive, mesohaline culture systems with two levels of biofloc management. Aquacultural Engineering 45:127-136.

Rudacille, J. B. and C. C. Kohler. 2000. Aquaculture performance comparison of sunshine bass, palmetto bass, and white bass. North American Journal of Aquaculture 62:114-124.

Schrader, K. K., B. W. Green, and P. W. Perschbacher. 2011. Development of phytoplankton communities and common off-flavors in a biofloc technology system used for the culture of channel catfish (Ictalurus punctatus). Aquacultural Engineering 45:118-126.

Schveitzer, R., R. Arantes, P. F. S. Costódio, C. M. do Espírito Santo, L. V. Arana, W. Q. Seiffert, and E. R. Andreatta. 2013. Effect of different biofloc levels on microbial activity, water quality and performance of Litopenaeus vannamei in a tank system operated with no water exchange. Aquacultural Engineering 56:59-70.

Smith, T. I. J., W. E. Jenkins, and R. V. Minton. 1990. Production of advanced fingerling and subadult striped bass and striped bass hybrids in earthen ponds. Pages 121-139 in R. M. Harrell, J. H. Kerby, and R. V. Minton, editors. Culture and propagation of striped bass and its hybrids. Striped Bass Committee, Southern Division, American Fisheries Society, Bethesda, Maryland, USA.

Turano, M. J., R. J. Borski, and H. V. Daniels. 2007. Compensatory growth of pond-reared hybrid striped bass, Morone chrysops $\times$ Morone saxatilis, fingerlings. Journal of the World Aquaculture Society 38:250-261.

Volkman, E. T., C. C. Kohler, and S. T. Kohler. 2004. Assessment of floating vertical raceways for the culture of phase-II hybrid striped bass. North American Journal of Aquaculture 66:125-132.

Watts, C., L. A. Bright, S. Coyle, and J. Tidwell. 2016. Evaluation of stocking density during second-year growth of largemouth bass, Micropterus salmoides, raised indoors in a recirculating aquaculture system. Journal of the World Aquaculture Society 47:538-543. 